\title{
Modeling performance and nutritional requirements of pigs lots during growth and finishing
}

\author{
Modelagem do desempenho e das exigências nutricionais \\ de lotes suínos em crescimento e terminação
}

\begin{abstract}
Bruno Neutzling Fraga ${ }^{I^{*}}$ Paulo Alberto Lovatto ${ }^{\mathrm{I} \dagger}$ Paulo Roberto Nogara Rorato Vladimir de Oliveira ${ }^{\mathrm{I}}$ Carlos Augusto Rigon Rossi ${ }^{\mathrm{II}}$ Cheila Roberta Lehnen ${ }^{\text {III }}$
\end{abstract}

\section{ABSTRACT}

Determination of animal profile from production scenarios by modeling is essential to improve production. The objective of this study was to model and evaluate the performance, the supply and nutrients requirements for pigs, during the growing and finishing phases, in real production scenarios. Six scenarios with 2,200 animals, which consumed six ad libitum diets, were selected. The collected data from the production scenarios were modeled based on the average animal. Animals were housed at $65 \pm 7$ days old and weighing $22.11 \pm 1.41 \mathrm{~kg}$ and were slaughtered at $159 \pm 10$ days old and weighing $121.18 \pm 7 \mathrm{~kg}$. Average of the scenarios was greater than $0.27 \mathrm{~kg}$ for consumption and $0.12 \mathrm{~kg}$ for weight gain; feed conversion was equivalent to the standard animal profile (SAP). Scenarios were $1.60 \mathrm{~g}$ higher for the requirement and $2.67 \mathrm{~g}$ higher for daily digestible lysine per animal when compared to the SAP. Production scenarios showed differences between performance, supply and nutrient requirements for pigs during the growing and finishing phases. Modeling is a tool that can be used to describe and compare the characteristics of each production scenario.

Key words: animal production, animal profile, InraPorc ${ }^{\circledR}$, lysine.

\section{RESUMO}

A determinação do perfil animal de cenários de produção, por modelagem, é imprescindivel para melhorar a produção. $O$ objetivo deste estudo foi modelar e avaliar o desempenho zootécnico, o fornecimento e as exigências de nutrientes para suínos nas fases de crescimento e terminação em cenários de produção reais. Foram selecionados seis cenários com total de 2.200 animais que consumiram seis dietas ad libitum. Os dados coletados nos cenários de produção foram modelados com base na média animal. Os animais foram alojados com $65 \pm 7$ dias de idade e 22,11 $\pm 1,41 \mathrm{~kg}$ de peso e foram abatidos com $159 \pm 10$ dias e $121,18 \pm 7 \mathrm{~kg}$. A média dos cenários foi superior a $0,27 \mathrm{~kg}$ em consumo e $0,12 \mathrm{~kg}$ em ganho de peso, a conversão alimentar foi equivalente ao perfil animal padrão (PAP). Os cenários foram superiores em 1,60g para exigência e 2,67g para fornecimento de lisina digestivel diária por animal em relação ao PAP. Os cenários de produção apresentam diferenças para desempenho zootécnico, fornecimento e exigências de nutrientes para suinos nas fases de crescimento e terminação. A modelagem é uma ferramenta que pode ser utilizada para descrever e comparar as especificidades em cada cenário de produção.

Palavras-chave: produção animal, perfil animal, InraPorc ${ }^{\circledR}$, lisina.

\section{INTRODUCTION}

Industrial pig production is stimulated by the demand for quality animal protein conditioned to maximum animal performance based on diets with high nutrition concentrations and high costs. Food represents about two thirds of swine production costs, therefore reduce the value derived from this fraction is interesting from the economic point of view.

The methods used to estimate nutritional requirements are based on the response of the population (empirical) or individual (factorial) (HAUSCHILD et al., 2010). Results compilation provides tables with static data about nutritional recommendations for general animal profile, such as those published by ARC (1981), NRC (1998) and ROSTAGNO et al. (2011). These tables are conventionally used in industrial production systems to develop empirical diets and food programs.

\footnotetext{
'Departamento de Zootecnia, Universidade Federal de Santa Maria (UFSM), 97105-900, Santa Maria, RS, Brasil. E-mail: bnfraga@gmail.com. $\dagger$ In memorian. *Corresponding author.

"Departamento de Clínica de Grandes Animais, UFSM, Santa Maria, RS, Brasil.

IIIDepartamento de Zootecnia, Universidade Estadual de Ponta Grossa (UEPG), Ponta Grossa, PR, Brasil.
} 
Although functional, this procedure applies generalizations to specific scenarios and results in inaccuracies. These inaccuracies can have effects on performance, digestive and metabolic processes regarding protein and lipid deposition (FABIAN et al., 2003), and/or production costs.

Growth phenomena should be evaluated dynamically, depending on the response of the animal to ingested nutrients (SAUVANT et al., 1995), which requires the development of new concepts. The InraPorc ${ }^{\circledR}$ model uses the principles of swine nutrition, such as digestible amino acids, net energy (NOBLET et al., 2001) and the ideal protein, using a dynamic methodology that is both mechanistic and deterministic to represent the phenomena related to nutrition, feed, and genetics (VAN MILGEN et al., 2008). Determination of nutritional requirements is elementary in terms of production efficiency (POMAR et al., 2009), due to diets with higher nutritional precision according to animal profile.

Determining the animal profile of each production scenario (a result of interactions between food consumption, dynamics growth, nutrients use, and the influence of environment) is essential to improve feed efficiency and reduce diets cost and excretion of polluting elements. Studies to identify the specific nutritional requirements of animal profiles in a mechanical and dynamic way are important for balancing diets. In this context, the aim of this study was to model and evaluate the growth performance, supply, and nutrient demands of pigs during the growing and finishing phases in production scenarios.

\section{MATERIALS AND METHODS}

Data collection was carried out in an industrial pig production system in the northwest of Rio Grande do Sul, between August and November 2012. The criterion for sampling was an interval of three days, to delimit the number of farms and minimize climatic effects. Data were collected from six farms or production scenarios (PS), i.e. 1PS, 2PS, $3 \mathrm{PS}, 4 \mathrm{PS}$, 5PS and 6PS, with equivalent management protocols. The scenarios presented variations in terms of facilities, equipment, location and orientation, capacity, and total number of animals. These factors (environment) were implicit in the performance of the PS, as other studies have reported in the literature (DE LANGE et al., 2001; VAN MILGEN et al., 2008).
The scenarios showed an average of $367 \pm 186$ animals, with a minimum population of 200 (5PS) and maximum of 724 animals (6PS). In total, 2,200 animals were used in six mixed batches (females and castrated males). Recommendations for housing the animals were 64 days old and $22.00 \mathrm{~kg}$. The diet program followed a pre-established period, sequence and quantities of each diet for animals in each stage. Ingredients composition were analyzed (AOAC, 1995) and the diets (Table 1) were formulated based on nutritional requirements established through the historic growth performance of farms or the standard animal profile (SAP). Food program was ad libitum for all phases and PS. The diet and food programs of the SAP were used in the PS.

Data collection in the scenarios was conducted in randomly selected bays throughout the experimental period, representing at least $20 \%$ of the animals housed, with a maximum limit of four bays. This procedure was performed based on the literature (DE LANGE et al., 2001). In each scenario, data on animal performance were collected (age, weight and accumulated consumption of diets) of all pigs in the sample bays for each phase, according to the diet program.

The diet composition data, feed intake and animal performance, from each PS and SAP, were entered into InraPorc ${ }^{\circledR}$ software (INRAPORC ${ }^{\circledR}, 2010$ ) to parameterize the model. Parameterization allows characterizing the animal profile of the respective production scenario (VAN MILGEN et al., 2008). The data for each scenario were modeled based on the average animal for all the parameters and $2 \%$ diet loss was estimated (BROSSARD et al., 2009). The animal performance curves were calibrated and the nutritional requirements were modeled (ROSSI et al., 2013) to the standard animal profile and the six animal profiles evaluated. The data were submitted to descriptive statistical analysis and compared using absolute relation to the standard deviation.

\section{RESULTS AND DISCUSSION}

The performance data of the PS are shown in table 2. The characteristics of the animals in each PS were an average age of $65 \pm 7$ days old and weight of $22.11 \pm 1.41 \mathrm{~kg}$. These values are similar to the SAP, although the minimum age was 55 days (6PS) and the maximum was 72 days (1PS), which generated a variation of nine days in the scenarios for the SAP. Likewise, the minimum weight was $19.64 \mathrm{~kg}$

Ciência Rural, v.45, n.10, out, 2015. 
Table 1 - Nutritional composition and proximate diets of pigs in the growing and finishing phases.

\begin{tabular}{|c|c|c|c|c|c|c|c|}
\hline Ingredients & & In & GI & GII & GIII & $\mathrm{TI}$ & TII \\
\hline Corn & $\%$ & 58.82 & 61.12 & 60.71 & 60.47 & 45.03 & 46.27 \\
\hline Soybean meal & $\%$ & 25.00 & 24.50 & 25.10 & 25.50 & 21.80 & 20.50 \\
\hline Sorghum & $\%$ & - & - & - & - & 20.00 & 20.00 \\
\hline Whole rice meal & $\%$ & 5.00 & 5.00 & 5.00 & 5.00 & 5.00 & 5.00 \\
\hline Animal fat & $\%$ & 4.20 & 3.50 & 3.65 & 3.80 & 3.50 & 3.15 \\
\hline Meat meal & $\%$ & 3.50 & 3.00 & 2.80 & 2.70 & 1.70 & 2.00 \\
\hline Premix mineral-vitaminic ${ }^{1}$ & $\%$ & 1.50 & 1.00 & 1.00 & 1.00 & 1.25 & 1.50 \\
\hline Sodium chloride & $\%$ & 0.50 & 0.45 & 0.45 & 0.45 & 0.45 & 0.45 \\
\hline Limestone & $\%$ & 0.30 & 0.50 & 0.50 & 0.45 & 0.65 & 0.55 \\
\hline Adsorbent & $\%$ & 0.25 & 0.25 & 0.25 & 0.25 & 0.25 & 0.25 \\
\hline L-Lysine $78 \%$ & $\%$ & 0.45 & 0.34 & 0.27 & 0.19 & 0.19 & 0.18 \\
\hline DL-Methionine $84 \%$ & $\%$ & 0.27 & 0.19 & 0.15 & 0.11 & 0.10 & 0.09 \\
\hline L-Threonine $98.5 \%$ & $\%$ & 0.20 & 0.14 & 0.11 & 0.07 & 0.07 & 0.05 \\
\hline Phytase & $\%$ & 0.01 & 0.01 & 0.01 & 0.01 & 0.01 & 0.01 \\
\hline Nutritional composition $^{2}$ & & In & GI & GII & GIII & TI & TII \\
\hline Energy net & Kcal & 2563 & 2549 & 2553 & 2560 & 2563 & 2546 \\
\hline Crude protein & $\%$ & 19.25 & 18.79 & 18.84 & 18.85 & 17.41 & 17.04 \\
\hline Minerals & $\%$ & 5.31 & 4.96 & 4.95 & 4.90 & 4.92 & 5.03 \\
\hline Ether extract & $\%$ & 8.25 & 7.57 & 7.70 & 7.84 & 7.37 & 7.09 \\
\hline Gross fiber & $\%$ & 1.99 & 2.00 & 2.01 & 2.02 & 1.92 & 1.90 \\
\hline Calcium & $\%$ & 0.71 & 0.73 & 0.76 & 0.73 & 0.70 & 0.73 \\
\hline Phosphorus total & $\%$ & 0.74 & 0.72 & 0.71 & 0.75 & 0.68 & 0.72 \\
\hline Lysine digestive & $\%$ & 1.16 & 1.05 & 1.01 & 0.96 & 0.86 & 0.83 \\
\hline Methionine digestive & $\%$ & 0.46 & 0.40 & 0.37 & 0.34 & 0.32 & 0.30 \\
\hline Cysteine digestive & $\%$ & 0.47 & 0.41 & 0.38 & 0.35 & 0.32 & 0.30 \\
\hline Tryptophan digestive & $\%$ & 0.19 & 0.18 & 0.19 & 0.19 & 0.17 & 0.17 \\
\hline Threonine digestive & $\%$ & 0.78 & 0.71 & 0.68 & 0.65 & 0.60 & 0.57 \\
\hline Phenylalanine digestive & $\%$ & 0.80 & 0.79 & 0.80 & 0.81 & 0.75 & 0.73 \\
\hline Tyrosine digestive & $\%$ & 0.59 & 0.59 & 0.60 & 0.60 & 0.56 & 0.55 \\
\hline Leucine digestive & $\%$ & 1.20 & 1.20 & 1.21 & 1.21 & 1.20 & 1.19 \\
\hline Isoleucine digestive & $\%$ & 0.66 & 0.65 & 0.66 & 0.66 & 0.62 & 0.60 \\
\hline Valine digestive & $\%$ & 0.76 & 0.75 & 0.75 & 0.76 & 0.71 & 0.69 \\
\hline Histidine digestive & $\%$ & 0.45 & 0.44 & 0.45 & 0.45 & 0.41 & 0.40 \\
\hline Arginine digestive & $\%$ & 1.12 & 1.10 & 1.11 & 1.13 & 1.00 & 0.97 \\
\hline
\end{tabular}

In - Initial Diet; GI, GII and GIII - Growth Diets; TI and TII - Finishing Diets; ${ }^{1}$ Mineral and vitamin supplement per kilogram of product- In Vitamin (Vit.) A 666,667.00IU; Vit. D3 133,350.00IU; Vit. E 3,335.00IU; Vit. K3 200.00mg; Vit. B1 200.00mg; Vit. B2 400.00mg; Vit. B6

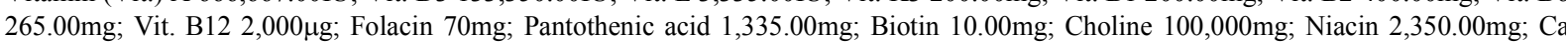
7.425\%; P available (Pavail.) 4.25\%; Cu 8,000mg; Fe 5,000mg; Zn 4,000mg; Mn 2,500mg; I 50mg; Se 15mg; Cl 4\%; S 0.414\%. GI Vit. A

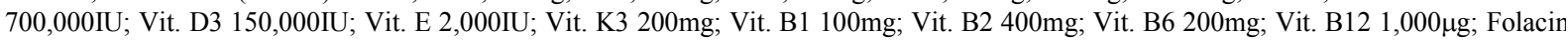
60mg; Pantothenic acid 1,500mg; Biotin 10mg; Choline 140,000mg; Niacin 2,000mg; Ca 9.533\%; Pavail. 8\%; Cu 10,666mg; Fe 6,666mg; Zn 5,333mg; Mn 3,333mg; I 66.7mg; Se 20mg; Cl 5.9\%; S 0.55\%. GII Vit. A 700,000IU; Vit. D3 150,000IU; Vit. E 2,000IU; Vit. K3

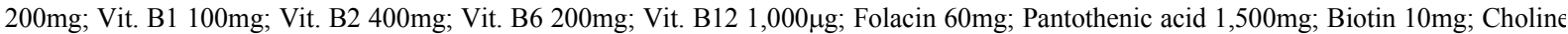
140,000mg; Niacin 2,000mg; Ca 13.6\%; Pavail. 8.2\%; Cu 10,666mg; Fe 6,666mg; Zn 5,333mg; Mn 3,333mg; I 66.7mg; Se 20mg; Cl 4.1\%; S 0.75\%. GIII Vit. A 700,000IU; Vit. D3 150,000IU; Vit. E 2,000IU; Vit. K3 200mg; Vit. B1 100mg; Vit. B2 400mg; Vit. B6 200mg; Vit.

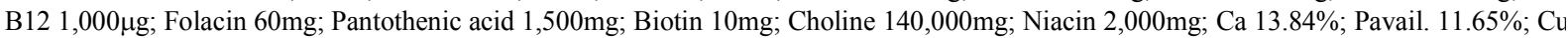
12,800mg; Fe 10,000mg; Zn 8,000mg; Mn 5,000mg; I 100mg; Se 30mg; Cl 4\%; S 0.66\%. TI Vit. A 336,000IU; Vit. D3 72,000IU; Vit. E

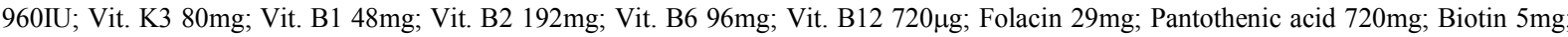
Choline 96,000mg; Niacin 960mg; Ca 8.8\%; Pavail. 7.92\%; Cu 12,800mg; Fe 8,000mg; Zn 6,400mg; Mn 4,000mg; I 80mg; Se 24mg; Cl 2.6\%; S 0.66\%. TII Vit. A 280,000IU; Vit. D3 60,000IU; Vit. E 800IU; Vit. K3 65mg; Vit. B1 40mg; Vit. B2 160mg; Vit. B6 80mg; Vit.

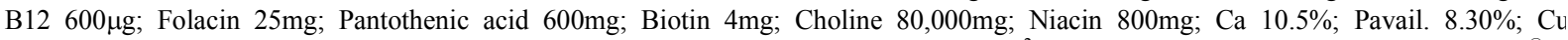
10,666mg; Fe 6,666mg; Zn 5,333mg; Mn 3,333mg; I 66.7mg; Se 20mg; Cl 5.9\%; S 0.55\%; ${ }^{2}$ Calculated based on fresh matter by InraPorc ${ }^{\circledR}$. 
Table 2 - Variables collected and animal performance modeled for production scenarios.

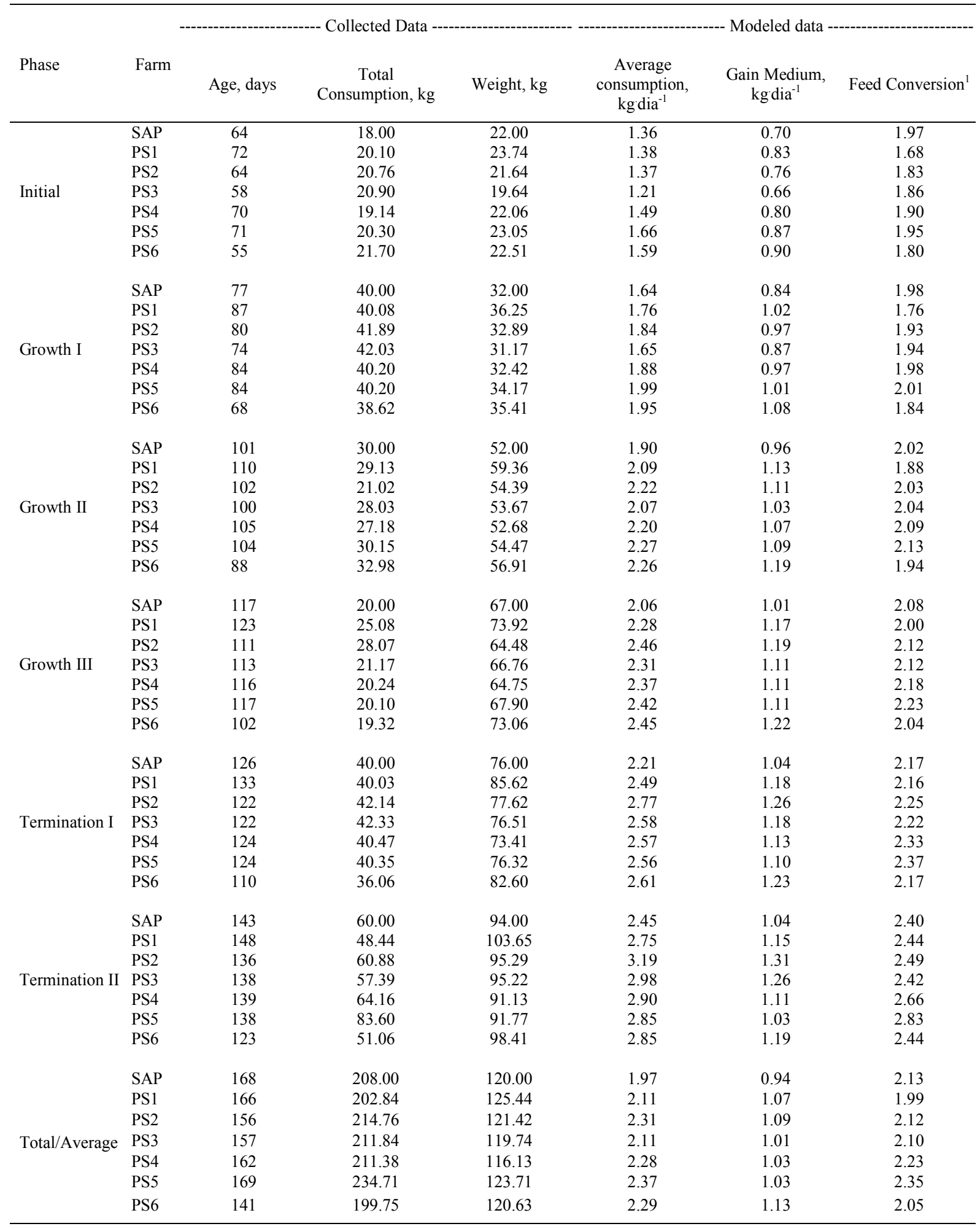

SAP-Standard Profile Animal; PS - Production Scenario; ${ }^{1}$ included $2 \%$ loss of diets. 
(3PS) and the maximum was $23.74 \mathrm{~kg}$ (1PS), with a variation of $2.05 \mathrm{~kg}$. Variations in age and weight at the beginning of the growing and finishing phases are determined by several factors such as weaning weight and nutrition program (MAHAN \& LEPINE, 1991). These factors are difficult to control (TOKACH et al., 2007) and are accepted as a natural component of the process or disregarded due to their complexity.

At the end of the period of $94 \pm 7$ days, the animals were slaughtered with an average weight of $121.18 \pm 7 \mathrm{~kg}$ and age of $159 \pm 10$ days old. Average slaughter weight of the scenarios was higher by only $1.18 \mathrm{~kg}$ and age was lower by 9 days compared to the SAP. The small variation in age and uniformity in weight is explained by the need for homogeneous carcasses. The variations between the scenarios were caused by intrinsic factors of production and/or goals and deadlines set by the industry.

The average performance of the scenarios for daily consumption was higher by $0.27 \pm 0.13 \mathrm{~kg}$ vs. the SAP; the minimum consumption was $2.11 \mathrm{~kg}$ (1PS) and the maximum was $2.37 \mathrm{~kg}$ (5PS). The scenarios presented a daily weight gain of $1.06 \pm 0.05 \mathrm{~kg}$ or $0.12 \mathrm{~kg}$ greater than the SAP. The lowest weight housing in PS resulted in the minimum daily gain of $1.01 \mathrm{~kg}$ (3PS), while $6 \mathrm{PS}$ generated $0.19 \mathrm{~kg}$ as the maximum gain, exceeding the standard. Feed conversion was irregular between scenarios and throughout the stages, but the final average of $2.14 \pm 0.13$ was equivalent to the standard.

The data collected in different scenarios show the growth behavior of the animals. This is a complex biological process, which involves an increase in the shape and composition of body mass over time. Mathematical modeling allows for the simulation of real systems to predict animal performance behavior and their nutritional requirements in different production scenarios (LOVATTO \& SAUVANT, 2001). Therefore, data from the diets and food programs and the animal profile were used as a basis for modeling simulations (VAN MILGEN et al., 2008).

Overall, the diet program and feeding program developed for the SAP supplied the lysine requirements in all phases. The requirement of daily digestible lysine estimated by InraPorc ${ }^{\circledR}$ for the SAP was of $15.95 \pm 2.69 \mathrm{~g}$ and the amount provided was $18.61 \pm 1.70 \mathrm{~g}$ (Figure 1). In this way, throughout the total period, an excess of $278.85 \mathrm{~g}$ per animal was expected, understood as a safety margin to adjust for the diversity of scenarios. This procedure is a common practice in conventional nutritional programs, according to the ARC (1981), NRC (1998) and ROSTAGNO et al. (2011), and is justified only by the impossibility of determining the requirements of the scenarios.

In general, there was excess lysine in all scenarios, and the animals got on average $17.6 \%$ more lysine than required. When comparing the average daily requirements for lysine, it was found that the scenarios had requirements $1.60 \mathrm{~g}$ higher than that of the SAP, but ingested $2.67 \mathrm{~g}$ more than expected. The InraPorc ${ }^{\circledR}$ software modeled the requirements and the supply of lysine of each scenario; therefore, it was possible to identify excesses in the phases and in the total period. With nutritional specificities, it is possible to suit the nutritional levels and set diet programs to reduce costs and nutrient excretion without affecting the maximum performance.

The inflection point was $18.51 \mathrm{~g}$ and occurred at 152 days or $103.32 \mathrm{~kg}$ of weight. The average of the scenarios resulted in demand for $20.40 \mathrm{~g}$ lysine at 138 days or $97.65 \mathrm{~kg}$ of weight. The inflection point indicates the age of the maximum lysine requirement for protein deposition (VAN MILGEN, 2008). The average of the scenarios shows that the animals had an early inflection point at $14 \pm 16$ days and at a $5.67 \mathrm{~kg}$ lower weight, but the maximum lysine requirement was superior to the standard by $1.89 \mathrm{~g}$. Among the scenarios, the greate stage difference for the inflection point was 42 days between 3PS (157 days) and 6PS (115 days). The biggest difference in weight for the maximum requirement of lysine was $42.7 \mathrm{~kg}$, found between $2 \mathrm{PS}$ and 5PS. These scenarios also showed the greatest difference between the maximum lysine required, with a difference of $3.6 \mathrm{~g}$.

Animals nutritional requirements are influenced by factors intrinsic to the animal, food, environment, and their interactions (NOBLET \& QUINIOU, 1999), so the requirements should not be taken as fixed values (FULLER, 2004). Based on the data collected in each PS, associated with pig nutrition concepts used by InraPorc $^{\circledR}$, it was possible to study the heterogeneity between animal performance and specific nutritional requirements. Differences in nutritional requirements are verifiable, but the adjustment of diet programs and food programs to various production scenarios requires further investigation. 


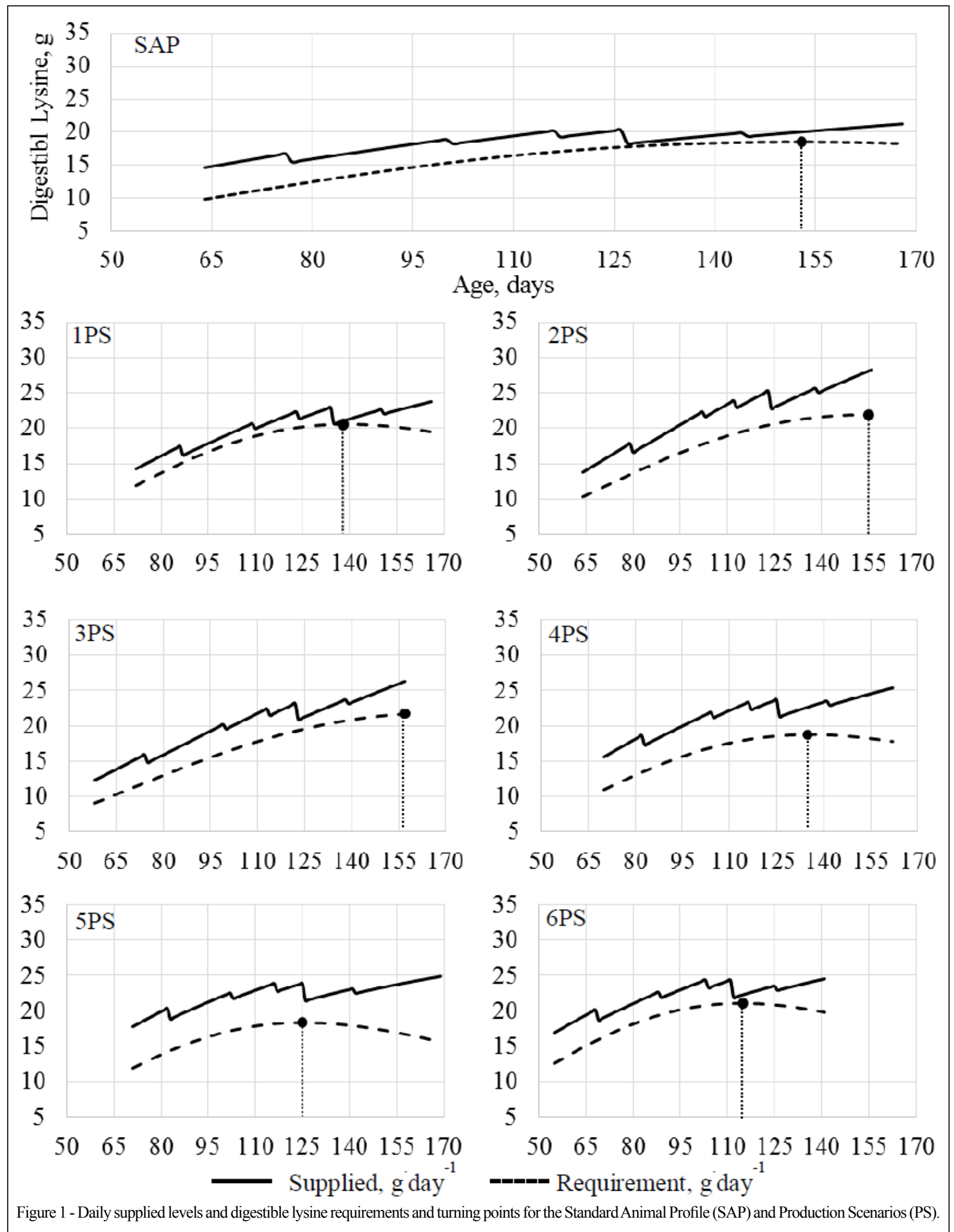

Ciência Rural, v.45, n.10, out, 2015. 


\section{CONCLUSION}

The production scenarios studied differed for performance, supply and nutrient requirements for pigs in the growing and finishing phases. Modeling is a tool that can be used to describe and compare the characteristics of each production scenario.

\section{ACKNOWLEDGMENTS}

The authors thank the Coordenação deAperfeiçoamento de Pessoal de Nível Superior (CAPES) for the scholarships awarded.

\section{REFERENCES}

AOAC. ASSOCIATION OF OFFICIAL ANALYTICAL CHEMISTS. Official methods of analysis of the association of the official analysis chemists. 16.ed. Arlington, 1995. 1750p.

ARC. The nutrients requirements of pigs: technical review. London, England: Commonwealth Agricultural Bureaux, 1981. 307p.

BROSSARD, L. et al. Modelling the variation in performance of a population of growing pig as affected by lysine supply and feeding strategy. Animal, v.3, p.1114-1123, 2009. Available from: <http:// dx.doi.org/10.1017/S1751731109004546>. Accessed: Feb. 19, 2014. doi: $10.1017 / \mathrm{S} 1751731109004546$

DE LANGE, C.F.M. et al. Application of pig growth models in commercial pork production. Canadian Journal of Animal Science, v.81, p.1-8, 2001. Available from: $<$ http://pubs.aic.ca/doi/ pdf/10.4141/A00-006>. Accessed: Feb. 11, 2014.

FABIAN, J. et al. Growth performance, dry matter and nitrogen digestibilities, serum profile, and carcass and meat quality of pigs with distinct genotypes. Journal of Animal Science, v.81, p.11421149, 2003. Available from: <http://www.journalofanimalscience. org/content/81/5/1142.full.pdf + html $>$. Accessed: Jan. 15, 2014.

FULLER, M.F. The encyclopedia of farm animal production. Wallingford, USA: CABI Publishing, 2004. 620p.

HAUSCHILD, L. et al. Systematic comparison of the empirical and factorial methods used to estimate the nutrient requirements of growing pigs. Animal, v.4, p.714-723, 2010. Available from: $<$ http://www.ncbi.nlm.nih.gov/pubmed/22444124>. Accessed: Feb. 10, 2014. doi: 10.1017/S1751731109991546.

INRAPORC $^{\circledR}$. InraPorc ${ }^{\circledR}$ : a tool to evaluate nutritional strategies in pigs. Saint-Gilles, France, 2010. 1.5.3.1.
LOVATTO, P.A.; SAUVANT, D. Modelagem aplicada aos processos digestivos e metabólicos do suíno. Ciência Rural, v.31, p.663-670, 2001. Available from: <http://www.scielo.br/pdf/cr/ v31n4/a17v31n4.pdf>. Accessed: Feb. 5, 2014. doi: 10.1590/ S0103-84782001000400017.

MAHAN, D.C.; LEPINE, A.J. Effect of pig weaning weight and associated nursery feeding programs on subsequent performance to 105 kilograms body weight. Journal of Animal Science, v.69, p.13701378, 1991. Available from: <http://www.journalofanimalscience.org/ content/69/4/1370.long >. Accessed: Jan. 8, 2014.

NOBLET, J.; QUINIOU, N. Principaux facteurs de variation du besoin en acides aminés du porc en croissance. Techni Porc, v.22, p.916, 1999. Available from: <http://www.ifip.asso.fr/sites/default/files/ pdf-documentations/tp1999n4noblet.pdf $>$. Accessed: Feb. 5, 2014.

NRC. National Research Council, nutrient requirements of swine. Washington: NRC, National Academy of Science, 1998. 189p.

POMAR, C. et al. Applying precision feeding techniques in growing-finishing pig operations. Revista Brasileira de Zootecnia, v.38, p.226-237, 2009. Available from: <http://www. scielo.br/pdf/rbz/v38nspe/v38nspea23.pdf $>$. Accessed: Jan. 23, 2014. doi: 10.1590/S1516-35982009001300023.

ROSSI, C.A.R. et al. Dietas ajustadas para suínos através do modelo InraPorc ${ }^{\circledR}$ : desempenho, características de carcaça e impacto econômico. Ciência Rural, v.43, p.689-695, 2013. Available from: <http://www.scielo.br/pdf/cr/v43n4/ a9513cr2012-0721.pdf>. Accessed: Feb. 23, 2014. doi: 10.1590/ S0103-84782013005000020.

ROSTAGNO, H.S. et al. Tabelas brasileiras para aves e suínos: composição de alimentos e exigências nutricionais. 3.ed. Viçosa: UFV, 2011. 252p

SAUVANT, D. et al. Systèmes d'unités d'alimentation et lois de réponse du porc aux régimes alimentaires. Journées Recherche Porcine, v.27, p.237-244, 1995. Available from: <http://www. journees-recherche-porcine.com/texte/1995/95txtAlim/A9507. pdf $>$. Accessed: Jan. 3, 2014.

TOKACH, M. et al. New tools to manage variability throughout the pork production chain London Swine Conference - Today's Challenges... Tomorrow's Opportunities. London, 2007.p1933. Available from: <http://www.londonswineconference.ca/ proceedings/2007/LSC2007_MTokach.pdf>. Accessed: Feb. 21, 2014.

VAN MILGEN, J. et al. InraPorc: a model and decision support tool for the nutrition of growing pigs. Animal Feed Science and Technology, v.143, p.387-405, 2008. Available from: <http:// www.sciencedirect.com/science/article/pii/S0377840107001782>. Accessed: Feb. 5, 2014. doi: 10.1016/j.anifeedsci.2007.05.020. 